Pesq. Vet. Bras. 37(2):129-136, fevereiro 2017 DOI: 10.1590/S0100-736X2017000200006

\title{
Molecular epidemiology of Anaplasma platys, Ehrlichia canis and Babesia vogeli in stray dogs in Paraná, Brazil ${ }^{1}$
}

\begin{abstract}
Claudia M. Ribeiro ${ }^{2 *}$, Aldair C. Matos ${ }^{3}$, Thainá Azzolini² ${ }^{2}$ Everton R. Bones², Eduardo A. Wasnieski ${ }^{2}$, Virgínia B. Richini-Pereira ${ }^{4}$, Simone B. Lucheis ${ }^{5}$ and Odilon Vidotto ${ }^{3}$

ABSTRACT.- Ribeiro C.M., Matos A.C., Azzolini T., Bones E.R., Wasnieski E.A., Richini-Pereira V.B., Lucheis S.B. \& Vidotto 0. 2017. Molecular epidemiology of Anaplasma platys, Ehrlichia canis and Babesia vogeli in stray dogs in Paraná, Brazil. Pesquisa Veterinária Brasileira 37(2):129-136. Faculdade Educacional de Dois Vizinhos, União de Ensino do Sudoeste do Paraná, Av. Presidente Kennedy 2601, Dois Vizinhos, PR 85660-000, Brazil. E-mail: clau.mribeiro@hotmail.com

Hemoparasitic infections are tick-borne diseases, which affect animals and humans. Considering the importance of canine hemoparasitic infections in veterinary clinics, this study aimed to determine the occurrence of Anaplasma platys, Ehrlichia canis and Babesia vogeli in blood samples from 182 dogs not domiciled in the city of Pato Branco, southwestern region of Paraná State, Brazil, using polymerase chain reaction (PCR). The prevalence of $A$. platys and $B$. vogeli was $32.9 \%$ and $10.9 \%$ respectively, and $A$. platys infection prevailed $(\mathrm{p}<0.001)$. The number of dogs positive for $A$. platys was larger in Winter $(\mathrm{p}<0.05)$. All blood samples were negative for E. canis. In the dogs, infestation by Amblyomma cajennense predominated over that by Rhipicephalus sanguineus ( $\mathrm{p}<0.001)$; but there was no significant association between PCR and the variables presence of ticks, sex and age. Dogs infected by A. platys and B. vogeli showed thrombocytopenia, lymphopenia and leukocytosis; but there was no correlation between such hematological changes and infection by hemoparasites. This appears to be the first molecular study that demonstrates the existence of $A$. platys and B. vogeli in dogs from the southwestern region of Paraná.
\end{abstract}

INDEX TERMS: Anaplasma platys, Ehrlichia canis, Babesia vogeli, dogs, Paraná, canine thrombocytic anaplasmosis, canine monocytic ehrlichiosis, canine babesiosis, PCR.

RESUMO.- [Epidemiologia molecular de Anaplasma platys, Ehrlichia canis e Babesia vogeli em cães não domiciliados do Paraná.] As hemoparasitoses são enfermidades transmitidas por carrapatos que afetam os animais e os humanos. Considerando a importância das hemoparasitoses caninas na clínica médica veterinária, este estudo ob-

\footnotetext{
${ }^{1}$ Received on October 12, 2015.

Accepted for publication on June 6, 2016.

${ }^{2}$ Faculdade Educacional de Dois Vizinhos (FAED), União de Ensino do Sudoeste do Paraná (UNISEP), Av. Presidente Kennedy 2601, Dois Vizinhos, PR 85660-000, Brazil. *Corresponding author: clau.mribeiro@hotmail.com

${ }^{3}$ Departamento de Medicina Veterinária Preventiva, Centro de Ciências Agrárias, Universidade Estadual de Londrina (UEL), Rodovia Celso Garcia Cid Km 380, Londrina, PR 86051-980, Brazil.

${ }^{4}$ Núcleo de Ciências Biomédicas, Centro de Laboratórios Regionais Bauru II, Instituto Adolfo Lutz, Rua Rubens Arruda, Quadra 6, Bauru, SP 17015110, Brazil.

${ }^{5}$ Agência Paulista de Tecnologia dos Agronegócios (APTA), Gabiente da Coordenadoria, Departamento de Descentralização do Desenvolvimento, Av. Rodrigues Alves 4040, Bauru, SP 17030-000, Brazil.
}

jetivou determinar a ocorrência de Anaplasma platys, Ehrlichia canis e Babesia vogeli em amostras de sangue de 182 cães não domiciliados do município de Pato Branco, região sudoeste paranaense, Brasil, utilizando a reação em cadeia da polimerase (PCR). A prevalência de A. platys e B. vogeli foi de $32,9 \%$ e $10.9 \%$, respectivamente, predominando a infecção por A. platys $(\mathrm{p}<0,001)$. Constatou-se um maior número de cães positivos para $A$. platys no período do inverno $(\mathrm{p}<0.05)$. Todas as amostras de sangue foram negativas para E. canis. Nos cães, a infestação por Amblyomma cajennense prevaleceu sobre a infestação por Rhipicephalus sanguineus $(\mathrm{p}<0,001)$, mas não foi observada associação significativa entre a PCR e as variáveis presença de carrapatos, sexo e idade. Cães infectados por A. platys e B. vogeli apresentaram trombocitopenia, linfopenia e leucocitose, porém não houve correlação destas alterações hematológicas com a infecção pelos hemoparasitas. Este é o primeiro estudo molecular que demonstra a existência de A. platys e de $B$. vogeli em cães da região sudoeste paranaense. 
TERMOS DE INDEXAÇÃO: Anaplasma platys, Ehrlichia canis, Babesia vogeli, cães, Paraná, anaplasmose trombocítica canina, erliquiose monocítica canina, babesiose canina, PCR.

\section{INTRODUCTION}

Canine tick-borne diseases are caused by bacteria or protozoa that parasitize blood cells and are transmitted by ticks. Among the etiologic agents of hemoparasitic infections, Ehrlichia canis, Anaplasma platys and Babesia vogeli are worthy of note due to their wide geographic distribution and high prevalence (Ramos et al. 2009, Araújo et al. 2015).

E. canis is a Gram-negative bacterium that shows tropism for monocytes and macrophages of dogs. It is the etiologic agent of canine monocytic ehrlichiosis (CME) (Rikihisa 2000), a disease that leads to varied morbidity and mortality rates since it can be acute, subclinical or chronic and manifest as diverse clinical signs such as lethargy, anorexia, pale mucous membranes, fever, bilateral uveitis and thrombocytopenia; in the most serious cases, there is severe anemia (hematocrit $<25 \%$ ), petechiae, epistaxis and pancytopenia (Shipov et al. 2008, Das \& Konar 2013). Transmission of E. canis occurs by means of nymphs and adults of the tick Rhipicephalus sanguineus (Bremer et al. 2005). E. canis is also pathogenic for humans since some strains that cause human ehrlichiosis are genetically and antigenically identical to the strains that cause CME (Perez et al. 2006, Vieira et al. 2013a).

Canine thrombocytic anaplasmosis (CTA) has as etiologic agent the Gram-negative bacterium A. platys, which shows tropism for blood platelets (Rikihisa 2000). The epidemiology of CTA has not been fully elucidated yet, and little is known about the vectors involved in the transmission of this bacterium. So far, the probable vector of $A$. platys is $R$. sanguineus since molecular studies have detected the DNA of this bacterium in this tick (Simpson et al. 1991, Sanogo et al. 2003). CTA is characterized by alternate periods of thrombocytopenia which cyclically appear and disappear at every 1-2 weeks (Gaunt et al. 1990, Dyachenko et al. 2012). Most dogs are asymptomatic, but clinical signs such as fever, lethargy, anorexia, pale mucous membranes, petechiae, bilateral uveitis and epistaxis have already been described (Glaze \& Gaunt 1986, Caprariis et al. 2011). A. platys also has a zoonotic potential since its genetic material was recently detected in a female veterinarian from the USA (Maggi et al. 2013) and in women from Venezuela (Arraga-Alvarado et al. 2014).

In Brazil, $B$. vogeli is the major etiologic agent of canine babesiosis and its transmission occurs by means of larvae, nymphs and adults of $R$. sanguineus (Shortt 1973). In the subclinical form of the disease, animals are asymptomatic. Dogs that develop the clinical form show especially fever, anemia, hemoglobinuria, jaundice and neurological disorders (Salem \& Farag 2014, Girotto-Soares \& Soares 2015). However, the most severe cases of canine babesiosis are related to co-infection with other hemoparasites (Caprariis et al. 2011).

These pathogens are generally detected based on blood smears or serological tests, which have low sensitivity and specificity, impairing the determination of the prevalence of such hemoparasites (Silva et al. 2012a, Araujo et al. 2015). Nevertheless, molecular techniques are highly sensitive and specific and can accurately determine the infection status in dogs (Ramos et al. 2009). In Brazil, the prevalence of these hemoparasites, determined by means of molecular methods, can vary from 1.6 to $55 \%$ for $A$. platys (Ramos et al. 2009, Lasta et al. 2013, Sousa et al. 2013), from 16.4 to $57 \%$ for E. canis (Ramos et al. 2009, Silva et al. 2012a, Sousa et al. 2013) and from 3.3 to $57.9 \%$ for B. vogeli (Jojima et al. 2008, Sousa et al. 2013, Araújo et al. 2015), depending on the geographic region and the studied population.

Considering that hemoparasitic infections are important in the routine of dog medical clinics due to the high casuistry and that there is scarce information about the prevalence of hemoparasites in the southwestern region of Paraná, the present study aimed to determine the prevalence of infection by A. platys, E. canis and B. vogeli among dogs not domiciled in the city of Pato Branco, Paraná State, as well as to assess the epidemiological variables associated with hemoparasitic infections in this region.

\section{MATERIALS AND METHODS}

Description of the study area. The dogs evaluated in this study were from the city of Pato Branco, which is in the southwestern region of Paraná $\left(26^{\circ} 13^{\prime} 44^{\prime \prime} \mathrm{S}, 52^{\circ} 40^{\prime} 15^{\prime \prime} \mathrm{W}\right)$ and shows a total area of $539,415 \mathrm{Km}^{2}$; its population is estimated at 78,136 inhabitants and density at 144,85 hab./ $\mathrm{Km}^{2}$ (Fig.1). The climate in the region is humid subtropical ( $\mathrm{Cfa}$ ) and the average temperature in the coldest month is inferior to $18^{\circ} \mathrm{C}$, while in the hottest month it is above $22^{\circ} \mathrm{C}$, showing relatively hot summers, frequent frosts and rainfall well distributed over the year. In the city of Pato Branco, the agricultural sector predominates with corn and soybean planting, poultry and dairy cattle rearing (IBGE 2014, IAPAR 2015).

Dog population. Dogs not domiciled in Pato Branco were captured by the NGO "Associação Lima Protetora dos Animais de Pato Branco" and sent to the Veterinary Hospital of "União do Ensino do Sudoeste do Paraná - UNISEP" for surgical castration. The software Win Episcope 2.0 was used to calculate the number of dogs necessary to estimate the prevalence of Anaplasma platys, Ehrlichia canis and Babesia vogeli (Thrusfield 2007). The number of samples from animals that showed 5\% significance was 127 dogs; however, 182 dogs, male and female, of no defined breed and varied ages, were randomly selected. All dogs were subjected to clinical examination.

Blood samples. From August to November 2014, blood samples were collected from dogs through jugular vein puncture and stored in "vacutainer" tubes containing 10\% EDTA. From each sample, $2 \mathrm{~mL}$ aliquots were transferred to sterile "eppendorf" tubes and kept at $-20^{\circ} \mathrm{C}$ until subsequent use in DNA extraction and PCR.

Complete blood count. The blood samples collected with EDTA were homogenized and subjected to blood cell count in a veterinary hematology counter PocH-100iV Diff (Sysmex ${ }^{\circledR}$ ).

Collection and identification of ticks. During blood collection, dogs were examined for the presence of ticks. The found ticks were collected for taxonomical identification according to Aragão \& Fonseca (1961).

Extraction and amplification of DNA from Anaplasma platys, Ehrlichia canis and Babesia vogeli. Genomic DNA was extracted from $200 \mathrm{uL}$ blood by using the commercial kit DNeasyBlood \& Tissue (Qiagen ${ }^{\mathrm{TM}}$ ), according to the manufacturer's instructions, eluted in $50 \mu \mathrm{L}$ TE buffer and stored at $-20^{\circ} \mathrm{C}$ until use in PCR. 
To detect the DNA of $B$. vogeli, the primers CAN 626R (5'-GAA CTC GAA AAA GCC AAA CGA-3') and CAN 172F (5'-GTT TAT TAG TTT GAA ACC CGC-3') were employed to amplify a fragment of the $18 \mathrm{~S}$ ribosomal RNA gene (450bp) (Inokuma et al. 2004). PCR was carried out with a final volume of $25 \mathrm{uL}$, containing $5 \mathrm{uL}$ genomic DNA, 0.8pmol of each primer, $200 \mu \mathrm{M}$ dNTP, 10X PCR Reaction buffer, $2.0 \mathrm{mM} \mathrm{MgCL}_{2}$ and $1.25 \mathrm{U}$ Platinum $^{\mathrm{TM}}$ Taq DNA Polymerase (Invitrogen ${ }^{\circledR}$ ). The amplification conditions consisted of an initial cycle at $94^{\circ} \mathrm{C}$ for $5 \mathrm{~min}$, followed by 36 cycles at $94^{\circ} \mathrm{C}$ for $1 \mathrm{~min}$, annealing at $55^{\circ} \mathrm{C}$ for $1 \mathrm{~min}, 72^{\circ} \mathrm{C}$ for $1 \mathrm{~min}$ and a final extension step at $72^{\circ} \mathrm{C}$ for $7 \mathrm{~min}$.

The primers EcavB9-F (5'-CAT TAT CAT TTC AAT ACG TAA CTC-3') and EcavB9-R (5'-TTT TGA TTT TCT TCT GAC ATA GTG$\left.3^{\prime}\right)$ were used to amplify a fragment of the gene virB9 (959bp) from $E$. canis; for A. platys, the primers Platys-F (5'-AAG TCG AAC GGA TTT TTG TC-3') and Platys-R (5'-CTC TCC CGG ACT CTA GTC-3') were used to amplify a sequence of the $16 \mathrm{~S}$ ribosomal RNA gene (504bp) (Silva et al. 2012a). The amplification reactions for $E$. canis and $A$. platys were mounted in a total volume of $25 \mu \mathrm{L}$ containing $3 \mu \mathrm{L}$ genomic DNA, $0.8 \mathrm{pmol}$ of each primer, $200 \mu \mathrm{M}$ dNTP, 1X PCR Platinum buffer, $1.5 \mathrm{mM} \mathrm{MgCl}_{2}$ and 1.25U Platinum ${ }^{\mathrm{TM}}$ Taq DNA Polymerase (Invitrogen ${ }^{\circledR}$ ). The used thermal sequences were: initial cycle at $94^{\circ} \mathrm{C}$ for $5 \mathrm{~min}$, followed by 35 cycles at $94^{\circ} \mathrm{C}$ for $1 \mathrm{~min}$, annealing at $58^{\circ} \mathrm{C}$ for $E$. canis and at $60^{\circ} \mathrm{C}$ for $A$. platys for $1 \mathrm{~min}$, and final extension at $72^{\circ} \mathrm{C}$ for $7 \mathrm{~min}$.

As positive control of the reactions, DNA from the target pathogen was employed, while ultrapure water was used as negative control. PCR products underwent electrophoresis on 1.5\% agarose gel stained with SYBR ${ }^{\circledR}$ Safe DNA Gel Stain (Invitrogen ${ }^{\circledR}$ ) and visualized under UV light.

Sequencing and phylogenetic analysis. Four samples positive for $A$. platys and one sample positive for $B$. vogeli were sequenced with BigDye ${ }^{\circledR}$ Terminator v3.1 Cycle Sequencing Kit (Applied Biosystems ${ }^{\circledR}$ ) and the automated sequencer ABI 3500 Genetic Analyzer (Applied Biosystems ${ }^{\circledR}$ ). Multiple sequence alignment was carried out using ClustalW, while phylogenetic trees were built by adopting the Neighbor-Joining method and Mega 7 software (Kumar et al. 2016).

Statistical analysis. Association among epidemiological variables, laboratory tests and hemoparasite prevalence was analyzed according to Chi-square test $\left(\chi^{2}\right)$ and Fisher's Exact test, both at $95 \%$ confidence interval, using the statistical package

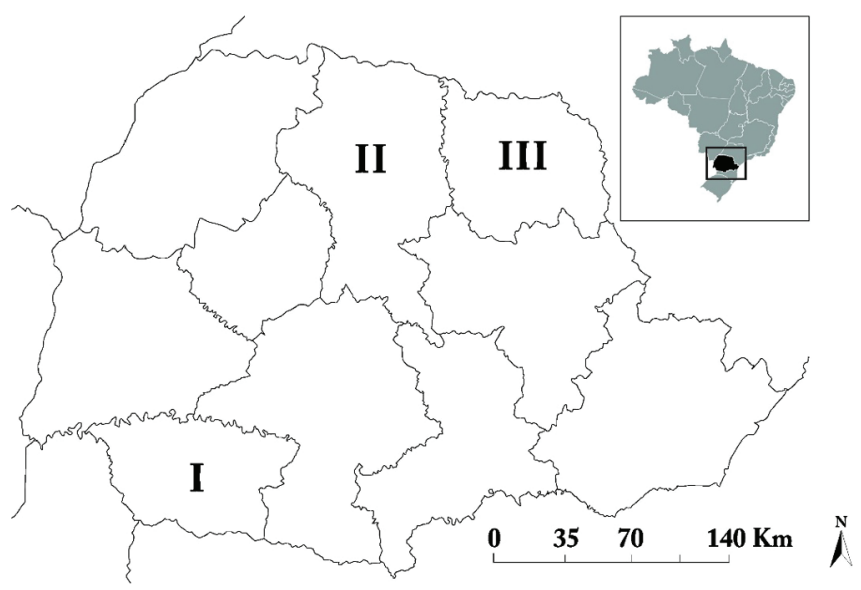

Fig.1. Map of Paraná State, Brazil, showing the southwestern region (I), the site of blood collection from not domiciled dogs, and the central north (II) and pioneer north (III) regions of the state.
GraphPad Prism $6{ }^{\circledR}$ (GraphPad Prism software, inc. San Diego, CA, USA). All comparisons were made at $5 \%$ significance level.

Ethics Committee.- All procedures adopted in the present study were approved by the Ethics Committee on Animal Use of "União de Ensino do Sudoeste do Paraná", Paraná State, Brazil (CEUA-001/2015).

\section{RESULTS}

\section{Molecular detection of hemoparasites}

Of the studied dogs, $40.1 \%(73 / 182)$ were infected with at least one of the three studied species, while $3.8 \%$ (07/182) were co-infected with Anaplasma platys and Babesia vogeli. Considering the examined blood samples, A. platys was detected in $32.9 \%(60 / 182)$ and $B$. vogeli in $10.9 \%$ samples (20/182), and infection by A. platys predominated over that by $B$. vogeli $(\mathrm{p}<0.001)$. No blood sample was positive for Ehrlichia canis.

Seasonal variability was not noted for $A$. platys or $B$. vogeli infection ( $\mathrm{p}>0.05)$; however, in August, there was a

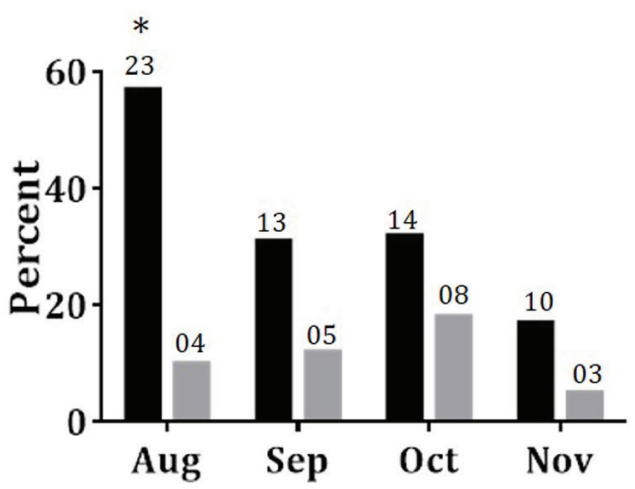

Fig.2. Percentage of dogs infected by Anaplasma platys and Babesia vogeli per month. Values above each bar indicate the number of animals infected per month. $\left({ }^{*}\right) \mathrm{p}<0.05$.

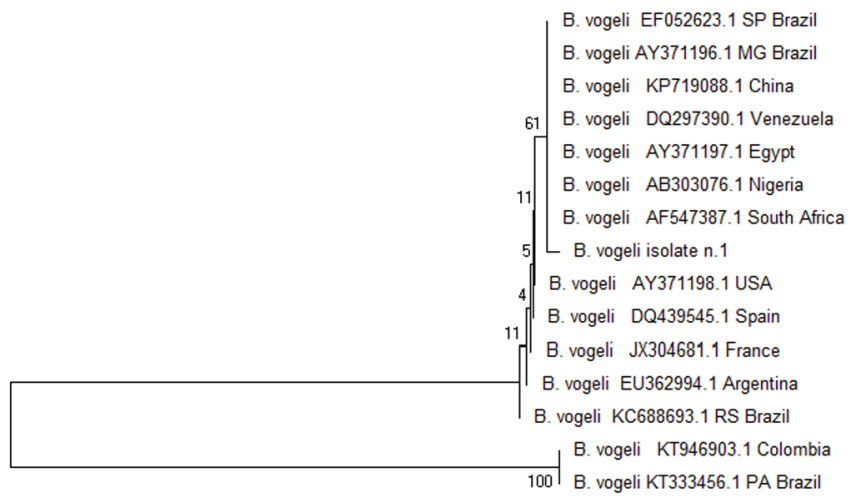

0.10

Fig.3. Phylogenetic analysis of partial 18S rRNA gene sequences of Babesia vogeli isolated from dogs from the states of Paraná (isolate 1), São Paulo (SP), Minas Gerais (MG), Rio Grande do Sul (RS) and Pará (PA), Brazil, and from dogs from different countries. The optimal tree in which the sum of branch length is equal to 1.32235987 is presented. The percentage of replicate trees in which the associated taxa clustered together in the bootstrap test (500 replicates) is shown next to the branches. The analysis involved 15 nucleotide sequences, totaling 59 positions in the final dataset. The scale bar represents a difference of 0.10 nucleotides between sequences. 
larger number of dogs infected by A. platys than by B. canis $(\mathrm{p}<0.05)$ (Fig.2).

\section{Phylogenetic analysis.}

The partial 18S rRNA gene sequence of B. vogeli was analyzed in comparison with the sequences deposited in GenBank. The sample B. vogeli isolate 1 showed $>99 \%$ similarity to the sequences EF052623.1, AY371196.1, KP719088.1, DQ297390.1, AY371197.1, AB303076.1, AF547387.1., AY371198.1, DQ439545.1, JX304681.1, EU362994.1, KC688693.1, KT946903.1 and KT333456.1 (Fig.3).

Alignment of partial 16S rRNA gene sequences isolated from $A$. platys revealed high similarity (>99\%) to the sequences deposited in GenBank under the accession numbers FJ755157.1, JF418996.1, KC989957.1, KJ832067.1, KC109446.1， KF576218.1， KT357373.1， DQ401045.1, KF360842.1， KC525894.1， HE856819.1， JX976181.1, JF683610.1, EU439943.1, LC018183.1, AY821826.1 and AF536828.1. Isolates 1, 2, 3 and 4 of A. platys clustered in the same ramification (Fig.4).

\section{Infestation by ticks}

Adult ticks were collected from 14.8\% (27/182) dogs and identified as Amblyomma cajennense and Rhipicephalus sanguineus. Considering dogs with ticks, $85.2 \%(23 / 27)$ were parasitized by $A$. cajennense and $14.8 \%(4 / 27)$ by $R$. sanguineus, indicating that $A$. cajennense incidence was greater among the studied animals $(\mathrm{p}<0.001)$. Ticks were not found in dogs infected by A. platys. Only one dog that was parasitized by $B$. vogeli was also infested by $R$. sanguineus at the moment of visual inspection and tick collection; thus, there was no correlation between presence of ticks and hemoparasite infection ( $p>0.05)$.

\section{Hematological changes}

After clinical examination, no animal had clinical signs such as fever, pale mucous membranes or lethargy; infections were subclinical. Hematological changes like thrombocytopenia, lymphopenia and leukocytosis were found in dogs in- fected by A. platys or B. vogeli; nevertheless, such alterations were not associated with infection by these pathogens (Table 1) ( $>0.05)$. There were no changes in the complete blood count of dogs co-infected with A. platys and B. vogeli.

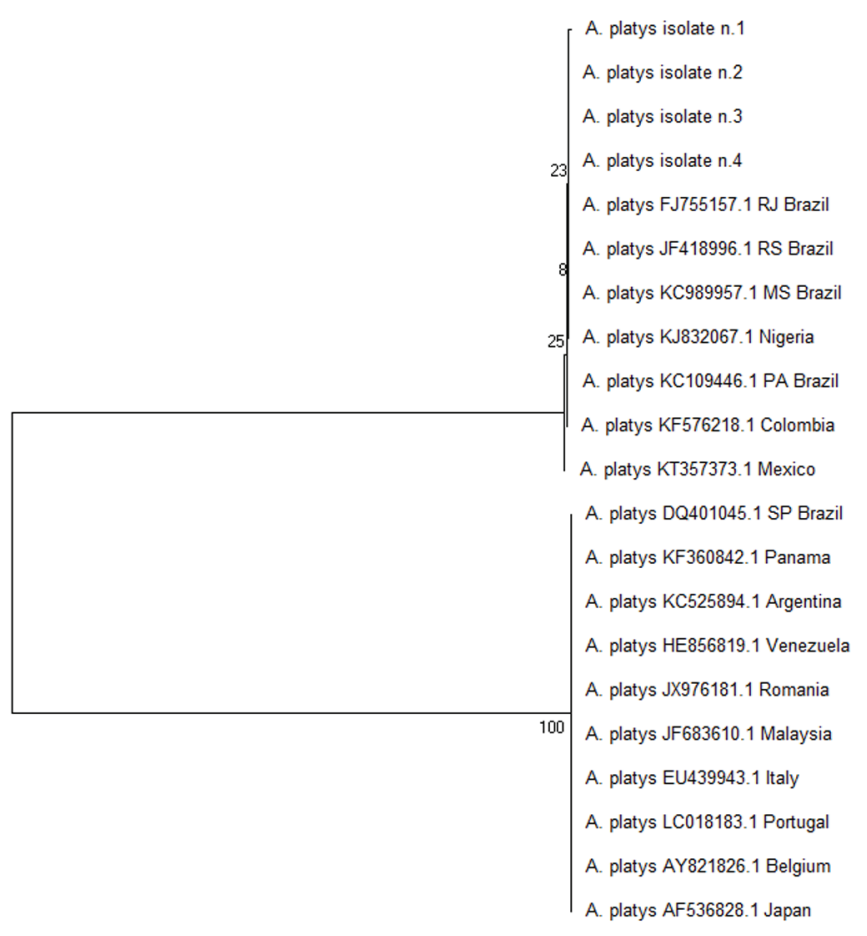

Fig.4. Neighbor-Joining Tree of partial 16S rRNA gene sequences of Anaplasma platys isolated from Paraná (isolate 1, 2, 3 and 4), Rio de Janeiro (RJ), Rio Grande do Sul (RS), Minas Gerais (MG), Pará (PA), São Paulo (SP), Brazil, and from countries in different continents. The optimal tree in which the sum of branch length is equal to 16.58608397 is presented. The percentage of replicate trees in which the associated taxa clustered together in the bootstrap test (500 replicates) is shown next to the branches. The analysis involved 21 nucleotide sequences, totaling 235 positions in the final dataset. The scale bar represents a difference of 2 nucleotides between sequences.

Table 1. Frequency of infection by Anaplasma platys and Babesia vogeli in not domiciled dogs, according to sex, age and hematological changes

\begin{tabular}{|c|c|c|c|c|c|c|c|c|c|c|c|c|}
\hline & \multicolumn{6}{|c|}{ Anaplasma platys } & \multicolumn{6}{|c|}{ Babesia vogeli } \\
\hline & \multicolumn{2}{|c|}{ Negative } & \multicolumn{2}{|c|}{ Positive } & \multicolumn{2}{|c|}{ Statistics } & \multicolumn{2}{|c|}{ Negative } & \multicolumn{2}{|c|}{ Positive } & \multicolumn{2}{|c|}{ Statistics } \\
\hline & $\mathrm{N}$ & $(\%)$ & $\mathrm{N}$ & $\%$ & X 2 (P Value) & OR $(95 \% \mathrm{CI})$ & $\mathrm{N}$ & $\%$ & $\mathrm{~N}$ & $\%$ & X 2 (P Value) & OR $(95 \% \mathrm{CI})$ \\
\hline Female & 68 & (55.7) & 30 & $(50.0)$ & $0.532(0.52)$ & $1.27(0.62-2.31)$ & 86 & (53.1) & 12 & $(60.0)$ & $0.342(0.63)$ & $0.74(0.2-1,9)$ \\
\hline Male & 54 & $(44.3)$ & 30 & $(50.0)$ & & & 76 & (46.9) & 8 & $(40.0)$ & & \\
\hline$<5$ years old & 101 & (82.8) & 47 & $(78.3)$ & $0.525(0.54)$ & $1.33(0.67-2.82)$ & 129 & $(79.6)$ & 19 & $(95.0)$ & $2.768(0.13)$ & $0.27(0.1-1.5)$ \\
\hline$>5$ years old & 21 & $(17.2)$ & 13 & (21.7) & & & 33 & (20.4) & 1 & $(5.0)$ & & \\
\hline Thrombocytopenia & & & & & & & & & & & & \\
\hline Yes & 0 & $(0.0)$ & 4 & (6.7) & $8.316(0.53)$ & $0.59(0.27-0.96)$ & 2 & $(1.3)$ & 2 & $(10.0)$ & $6.363(0.50)$ & $0.13(0.10-0.84)$ \\
\hline No & 122 & $(100.0)$ & 56 & (93.3) & & & 160 & (98.7) & 18 & $(90.0)$ & & \\
\hline Lymphopenia & & & & & & & & & & & & \\
\hline Yes & 5 & $(4.1)$ & 24 & $(40.0)$ & $3.780(0.43)$ & $0.67(0.65-0.72)$ & 22 & $(13.6)$ & 7 & $(35.0)$ & $6.098(0.42)$ & $0.21(0.10-0.81)$ \\
\hline No & 117 & (95.9) & 36 & $(60.0)$ & & & 140 & $(86.4)$ & 13 & $(65.0)$ & & \\
\hline Leukocytosis & & & & & & & & & & & & \\
\hline Yes & 2 & $(1.6)$ & 3 & $(5.0)$ & $0.731(0.33)$ & $0.35(0.19-0.51)$ & 3 & $(1.8)$ & 2 & $(10.0)$ & $4.424(0.49)$ & $0.16(0.02-1.08)$ \\
\hline No & 120 & (98.4) & 57 & $(95.0)$ & & & 159 & (98.2) & 18 & $(90.0)$ & & \\
\hline
\end{tabular}

$\overline{\mathrm{N}=\text { number }}$ 


\section{Age and sex of dogs}

There was no association between positive PCR and the variables sex and age of dogs ( $p>0.05)$ (Table 1$)$.

\section{DISCUSSION}

Tick-borne pathogens are of great importance for small animal clinics and public health since they are increasingly prevalent among dogs and can infect humans (Jojima et al. 2008, Maggi et al. 2013). In Brazil, there is lack of information about the distribution of hemoparasites and their vectors. This is the first study that evaluates the prevalence of Anaplasma platys, Ehrlichia canis and Babesia vogeli among dogs not domiciled in the southwestern region of Paraná, South of Brazil.

All PCR-tested blood samples were negative for $E$. $c a$ nis. The absence of E. canis in this study differs from the results obtained in other regions of Paraná State. In the city of Jataizinho, pioneer north region of Paraná, E. canis prevalence was $16.4 \%$, while co-infection with $E$. canis and $A$. platys was verified for $5.4 \%$ of the evaluated dogs (Silva et al. 2012a). E. canis was also detected in $21.7 \%$ of the dogs showing anemia and attended at a veterinary school hospital in the city of Londrina, central north region of Paraná (Dagnone et al. 2003). Serological tests in the city of Londrina demonstrated that dogs from the urban area were more infested by $R$. sanguineus and had greater seroprevalence for E. canis (64.7\%) than those from the rural area (25.7\%) (Vieira et al. 2013b). Seroprevalence for E. canis was also high in the city of Alvorada do Sul (42.4\%), central north region of Paraná (Vieira et al. 2013a).

CME is endemic to several Brazilian states, and E. canis frequency is high in São Paulo (40\%) (Ueno et al. 2009), Mato Grosso do Sul (45\%) (Sousa et al. 2013), Bahia (25.6\%) (Guedes et al. 2015), Pernambuco (57\%) (Ramos et al. 2009) and Paraíba (25\%) (Rotondano et al. 2015). Nevertheless, in Rio Grande do Sul, the occurrence of this rickettsia is low or null, although $R$. sanguineus is present (Saito et al. 2008, Lasta et al. 2013).

This difference in E. canis occurrence between the southwestern region of Paraná and other regions of this and other Brazilian states could be explained by the genetic diversity of $R$. sanguineus present in this region. Phylogenetic studies have indicated that there are two genetically distinct populations of $R$. sanguineus in Latin America: a tropical and a temperate one (Moraes-Filho et al. 2011). The tropical $R$. sanguineus strain is of African origin and is distributed over the tropical and subtropical America, i.e., north of Argentina, Colombia, Paraguay, Peru, and the Brazilian states Piauí, Pernambuco, Paraíba, Mato Grosso, Mato Grosso do Sul, Minas Gerais, Espírito Santo, São Paulo and Santa Catarina; the temperate R. sanguineus strain is of European origin and is present in temperate Latin America, i.e., Chile, Argentina, Uruguay, and the Brazilian state Rio Grande do Sul (Moraes-filho et al. 2011, Nava et al. 2012). $R$. sanguineus from tropical America has high vector competence and is capable of transmitting E. canis. On the other hand, $R$. sanguineus from temperate Latin America has low vector competence, not transmitting E. canis to dogs (Moraes-Filho et al. 2013).
Cicuttin et al. (2015) demonstrated that both tropical and temperate $R$. sanguineus strains are found in the north region of Argentina. Those authors found the tropical $R$. sanguineus strain infected by E. canis in the cities of Ingeniero Juárez, Formosa Province and Coronel Juan Solá, Salta Province; these provinces are at the frontier with Paraguay and Bolivia. For the cities Machagai and Juan José Castelli, both in Chaco Province, and in the city of Oberá in Misiones Province, only temperate R. sanguineus strains were found and all these ticks were negative for $E$. canis. Misiones Province is at the frontier with the southwestern region of Paraná, and Oberá City is located at less than 500 $\mathrm{Km}$ apart from Pato Branco City. Therefore, it is possible that the temperate $R$. sanguineus strain predominates in the southwestern region of Paraná and that E. canis transmission to dogs does not occur, as observed in this study. However, future studies are needed to determine the $R$. sanguineus strain that prevails in this region and its vector competence for $E$. canis. In addition, more blood samples from urban and rural dogs should be analyzed by using primers that amplify fragments from other target genes of $E$. canis in order to conclude whether this pathogen is absent or its occurrence is rare in the southwestern region of Paraná.

In the present study, $B$. vogeli prevalence detected by means of PCR was lower $(10.9 \%)$ than that obtained in the central north region of Paraná State (23.4\%) (Jojima et al. 2008 ) but similar to that found in Minas Gerais (10.8\%) (Costa-Júnior et al. 2012) and higher than those noted for the states of São Paulo (8\%) (O'Dwyer et al. 2009), Mato Grosso do Sul (3.3\%) (Sousa et al. 2013) and Maranhão (3.3\%) (Silva et al. 2012b).

$B$. vogeli isolate in this study clustered in the same subclade as strains found in dogs from the states of São Paulo and Minas Gerais and from countries belonging to different continents, such as Venezuela, Nigeria, South Africa, Egypt and China (Matjila et al. 2004, Passos et al. 2005, Rey-Valeirón et al. 2007, Sasaki et al. 2007, Oliveira et al. 2009, Xu et al. 2015) (Fig.3).

Even though $B$. vogeli was detected, $R$. sanguineus was only found in a few dogs and the tick $A$. cajennense was prevalent $(\mathrm{p}<0.001)$. This occurred because the studied dogs were from a predominantly rural area, where $A$. $c a$ jennense is abundant; $R$. sanguineus is found especially in urban areas (Costa-Júnior et al. 2013, Vieira et al. 2013a). As a probable consequence, $B$. vogeli frequency was lower than that verified in the central north region of Paraná, a predominantly urban area. These data agree with those obtained by O'Dwyer et al. (2009), who reported that infection by Babesia spp. in dogs from rural areas is not as prevalent as in urban areas.

Considering the hemoparasites investigated in the southwestern region of Paraná, infection by $A$. platys prevailed (32.9\%) $(\mathrm{p}<0.001)$; however, Silva et al. (2012a) detected lower prevalence of this bacterium in the pioneer north region of Paraná, a predominantly urban area. In fact, the frequency of $A$. platys among dogs has already been reported to be greater in the rural than in the urban zone (Costa-Júnior et al. 2013). This bacterium was also 
identified in the states of Pernambuco (55\%) (Ramos et al. 2009), Minas Gerais (13.9\%) (Costa-Júnior et al. 2013), Rio de Janeiro (14.8\%) (Ferreira et al. 2007), São Paulo (3.9\%) (Dagnone et al. 2009) and Rio Grande do Sul (14\%) (Lasta et al. 2013).

In this study, the isolates 1, 2, 3 and 4 of $A$. platys were clustered in one same subclade and had evolutionary homology to strains from the states of Pará, Mato Grosso do Sul, Rio de Janeiro and Rio Grande do Sul and from the countries: Colombia and Nigeria (Fig.4) (Lasta et al. 2013, Rufino et al. 2013, Sousa et al. 2013, Miranda \& Mattar 2015).

Co-infection with A. platys and B. vogeli was verified for $3.8 \%$ of the dogs. These results corroborate those found by Otranto et al. (2010) and Caprariis et al. (2011) in Italy and suggest that $R$. sanguineus is the vector responsible for the transmission of both pathogens. However, it is important to consider that in August, a dry winter month, there was a larger number of dogs infected by A. platys than by B. canis $(\mathrm{p}<0.05)$ and, during this period, very few dogs are exposed to infestation by $R$. sanguineus. This tick was considered the major transmitter of A. platys, but epidemiological studies have detected the DNA of this anaplasmataceae in a low percentage of $R$. sanguineus, demonstrating that $A$. platys is more prevalent in dogs than in this tick (Brown et al. 2005, Ybañez et al. 2012, Latrofa et al. 2014).

It is possible that other tick species act as vectors of A. platys, since molecular tools have detected the DNA of this anaplasmataceae in nymphs and adults of the ixodidea Haemaphysalis longicornis and H. flava, as well as in larvae and nymphs of Ixodes nipponensis (Chae et al. 2008). Other arthropods are also thought to be capable of transmitting A. platys. Brown et al. (2005) detected the DNA of A. platys in Heterodoxus spiniger and suggested that this louse species can be the vector of this bacterium, especially in winter months, because the prevalence of $A$. platys and H. spiniger in this season is high.

There was no correlation between infection by A. plat$y$ s and infestation by A. cajennense ( $\mathrm{p}>0.05)$, since no ticks were found in dogs positive for this bacterium. However, it must be considered that A. cajennense is a trioxenic tick, which remains in a certain host for a few days to feed on lymph and blood and then returns to the soil for ecdysis. This was the only tick species found in the dogs investigated from mid August to September. In fact, between May and October, when the average temperatures and rainfall are low, larval and nymph instars of $A$. cajennense predominate on the pastures or parasitizing the animals (Oliveira et al. 2000). Thus, we support the hypothesis that $A$. cajennense can act as a vector of $A$. platys in the winter, which must be proven by future studies.

Regardless of sex and age, dogs had equal opportunity to become infected with $A$. platys and B. vogeli, and there was no association of these variables with infection by hemoparasites. Molecular methods have demonstrated similar results for A. platys in Minas Gerais (Costa-Júnior et al. 2013) and for B. vogeli in Maranhão (Silva et al. 2012b).

Thrombocytopenia has been cited as the most frequent hematological change found in CTA dogs, initially due to the destruction of blood platelets caused by A. platys proliferation and then as a consequence of immune-mediated mechanisms (Bodié et al. 2011). Considering canine babesiosis, thrombocytopenia has been reported to manifest especially when there is co-infection with other pathogens (Caprariis et al. 2011, Silva et al. 2012b). However, in the present study most dogs with thrombocytopenia were negative according to PCR, and there was no association between infection by hemoparasites and thrombocytopenia $(\mathrm{p}>0.05)$.

Leukocytosis and lymphopenia were observed in dogs positive for A. platys and B. vogeli; however, there was no association between infection and hematological changes $(p>0.05)$. Nevertheless, leukocytosis due to neutrophilia has been cited as one of the most frequent changes in canine babesiosis (Girotto-Soares \& Soares 2015), while some dogs can present leucopenia (Jojima et al. 2008).

\section{CONCLUSIONS}

In the present study, infection by Anaplasma platys and Babesia vogeli was described for the first time in the southwestern region of Paraná based on the detection of DNA of these pathogens in the blood of dogs not domiciled in the city of Pato Branco.

Ehrlichia canis was not found in this region and the dogs were more infested by Amblyoma cajennense than by Rhipicephalus sanguineus.

Results demonstrate that hematological changes should not be used separately to establish a diagnosis of CTA or canine babesiosis, but should be evaluated in association with molecular methods.

This study provides epidemiological information about the prevalence of pathogens transmitted by ticks in the state of Paraná, Brazil, contributing to small animal clinics in order to establish control and preventive measures against hemoparasitic infection in dogs.

\section{REFERENCES}

Arraga-Alvarado C.M., Qurollo B., Parra O.C., Berrueta M.A., Hegarty B.C. \& Breitschwerdt E.B. 2014. Molecular evidence of Anaplasma platys infection in two women from Venezuela. Am. J. Trop. Med. Hyg. 91:11611165.

Aragão H.B. \& Fonseca F. 1961. Notas de ixodologia. VII Lista e chave para os representantes da fauna ixodológica brasileira. Mem. Inst. Oswaldo Cruz 59:115-129.

Araújo A.C., Silveira J.A.G., Azevedo S.S., Nieri-Bastos F.A., Ribeiro M.F.B., Labruna M.B. \& Horta M.C. 2015. Babesia canis vogeli infection in dogs and ticks in the semiarid region of Pernambuco, Brazil. Pesq. Vet. Bras. 35:456-461.

Bodié K., Gagne G.D., Sramek M.K., Desmond D.J., Abel S.J. \& Fagerland J.A. 2011. Asymptomatic macrothrombocytopenia in a young pure-bred beagle dog: a case report. Toxicol. Pathol. 39:980-987.

Bremer W.G., Schaefer J.J., Wagner E.R., Ewing S.A., Rikihisa Y., Needham G.R., Jittapalapong S., Moore D.L. \& Stich R.W. 2005. Transstadial and intrastadial experimental transmission of Ehrlichia canis by male Rhipicephalus sanguineus. Vet. Parasitol. 131:95-105.

Brown G.K., Martin A.R., Roberts T.K. \& Dunstan R.H. 2005. Molecular detection of Anaplasma platys in lice collected from dogs in Australia. Aust. Vet. J. 83:101-102.

Caprariis D., Dantas-Torres F., Capelli G., Mencke N., Stanneck D., Breitschwerdt E.B. \& Otranto D. 2011. Evolution of clinical, haematologi- 
cal and biochemical findings in young dogs naturally infected by vector-borne pathogens. Vet. Microbiol. 149:206-212.

Chae J.S., Yu do H., Shringi S., Klein T.A., Kim H.C., Chong S.T., Lee I.Y. \& Foley J. 2008. Microbial pathogens in ticks, rodents and a shrew in northern Gyeonggi-do near the DMZ, Korea. J. Vet. Sci. 9:285-293.

Cicuttin G.L., Tarragona E.L., De Salvo M.N., Mangold A.J. \& Nava S. 2015. Infection with Ehrlichia canis and Anaplasma platys (Rickettsiales: Anaplasmataceae) in two lineages of Rhipicephalus sanguineus sensu lato (Acari: Ixodidae) from Argentina. Ticks Tick Borne Dis. 6:724-729.

Costa-Júnior L.M., Zahler-Rinder M., Ribeiro M.F., Rembeck K., Rabelo E.M., Pfister K. \& Passos L.M. 2012. Use of a Real Time PCR for detecting subspecies of Babesia canis. Vet. Parasitol. 188:160-163.

Costa-Júnior L.M., Rembeck K., Passos L.M. \& Ribeiro M.F. 2013. Factors associated with epidemiology of Anaplasma platys in dogs in rural and urban areas of Minas Gerais State, Brazil. Prev. Vet. Med. 109:321-326.

Dagnone A.S., Morais H.S., Vidotto M.C., Jojima F.S. \& Vidotto O. 2003. Ehrlichiosis in anemic, thrombocytopenic, or tick-infested dogs from a hospital population in South Brazil. Vet. Parasitol. 117:285-290.

Dagnone A.S., Souza A.I., André M.R. \& Machado R.Z. 2009. Molecular diagnosis of Anaplasmataceae organisms in dogs with clinical and microscopical signs of ehrlichiosis. Revta Bras. Parasitol. Vet. 18:20-25.

Das M. \& Konar S. 2013. Clinical and hematological study of canine Ehrlichiosis with other hemoprotozoan parasites in Kolkata, West Bengal, India. Asian Pac. J. Trop. Biomed. 3:913-915.

Dyachenko V., Pantchev N., Balzer H.J., Meyersen A. \& Straubinger R.K. 2012. First case of Anaplasma platys infection in a dog from Croatia. Parasit. Vectors 5:49.

Ferreira R.F., Cerqueira A.M.F., Pereira A.M., Guimarães C.M., Sá A.G., Abreu F.S., Massard C.L. \& Almosny N.R.P. 2007. Anaplasma platys diagnosis in dogs: comparison between morphological and molecular tests. Intern. J. Appl. Res. Vet. Med. 5:113-119.

Gaunt S.D., Baker D.C. \& Babin S.S. 1990. Platelet aggregation studies in dogs with acute Ehrlichia platys infection. Am. J. Vet. Res. 51:290-293.

Glaze M.B. \& Gaunt S.D. 1986. Uveitis associated with Ehrlichia platys infection in a dog. J. Am. Vet. Med. Assoc. 189:916-917.

Girotto-Soares A. \& Soares J.F. 2015. Babesiose, p.77-86. In: Ribeiro C.M. (Ed.), Enfermidades Parasitárias por Protozoários em Pequenos Animais. Rubio, Rio de Janeiro.

Guedes P.E., Oliveira T.N., Carvalho F.S., Carlos R.S., Albuquerque G.R., Munhoz A.D., Wenceslau A.A. \& Silva F.L. 2015. Canine ehrlichiosis: prevalence and epidemiology in northeast Brazil. Revta Bras. Parasitol. Vet. 24:115-121.

IAPAR 2015. Instituto Agronômico do Paraná.

IBGE 2014. Estimativa populacional 2014. Instituto Brasileiro de Geografia e Estatística.

Inokuma H., Yoshizaki Y., Matsumoto K., Okuda M., Onishi T., Nakagome K., Kosugi R. \& Hirakawa M. 2004. Molecular survey of Babesia infection in dogs in Okinawa, Japan. Vet. Parasitol. 121:341-346.

Jojima F.S., Garcia J.L., Vidotto M.C., Balarin M.R., Fabretti A.K., Gasparini M.R., Coelho A.L. \& Vidotto O. 2008. Occurrence and molecular characterization of Babesia species in a canine hospital population in the Londrina Region, Parana State, Brazil. Revta Bras. Parasitol. Vet. 1:277-283.

Kumar S., Stecher G. \& Tamura K. 2016. MEGA7: Molecular evolutionary genetics analysis version 7.0 for bigger datasets. Mol. Biol. Evol. 22 .

Lasta C.S., Santos A.P., Messick J.B., Oliveira S.T., Biondo A.W., Vieira R.F., Dalmolin M.L. \& González F.H. 2013. Molecular detection of Ehrlichia canis and Anaplasma platys in dogs in Southern Brazil. Revta Bras. Parasitol. Vet. 22:360-366.

Latrofa M.S., Dantas-Torres F., Giannelli A. \& Otranto D. 2014. Molecular detection of tick-borne pathogens in Rhipicephalus sanguineus group ticks. Ticks Tick Borne Dis. 5:943-946.

Maggi R.G., Mascarelli P.E., Havenga L.N., Naidoo V. \& Breitschwerdt E.B. 2013. Co-infection with Anaplasma platys, Bartonella henselae and Candidatus Mycoplasma haematoparvum in a veterinarian. Parasit. Vectors 6:103.
Matjila P.T., Penzhorn B.L., Bekker C.P., Nijhof A.M. \& Jongejan F. 2004. Confirmation of occurrence of Babesia canis vogeli in domestic dogs in South Africa. Vet. Parasitol. 122:119-125.

Miranda J. \& Mattar S. 2015. Molecular detection of Anaplasma sp. and Ehrlichia sp. in ticks collected in domestical animals, Colombia. Trop. Biomed. 32:726-735.

Moraes-Filho J., Marcili A., Nieri-Bastos F.A., Richtzenhain L.J. \& Labruna M.B. 2011. Genetic analysis of ticks belonging to the Rhipicephalus sanguineus group in Latin America. Acta Trop. 117:51-55.

Moraes-Filho J., Soares J.F., da Silva Krawczak F., Lado P. \& Labruna M.B. 2013. Estudio de la competencia vectorial de Ehrlichia canis por cuatro poblacionesde Rhipicephalus sanguineus. Acta Med. Costaricense 55:93.

Nava S., Mastropaolo M., Venzal J.M., Mangold A.J. \& Guglielmone A.A. 2012. Mitochondrial DNA analysis of Rhipicephalus sanguineus sensu lato (Acari: Ixodidae) in the Southern Cone of South America. Vet. Parasitol. 190:547-555.

O’Dwyer L.H., Lopes V.V., Rubini A.S., Paduan K.S. \& Ribolla P.E. 2009. Babesia spp. infection in dogs from rural areas of São Paulo State, Brazil. Revta Bras. Parasitol. Vet.18:23-26.

Oliveira P.R., Borges L.M., Lopes C.M. \& Leite R.C. 2000. Population dynamics of the free-living stages of Amblyomma cajennense (Fabricius, 1787) (Acari:Ixodidae) on pastures of Pedro Leopoldo, Minas Gerais State, Brazil. Vet. Parasitol. 92:295-301.

Oliveira L.P., Cardozo G.P., Santos E.V., Mansur M.A., Donini I.A., Zissou V.G., Roberto P.G. \& Marins M. 2009. Molecular analysis of the rRNA genes of Babesia spp and Ehrlichia canis detected in dogs from Ribeirão Preto, Brazil. Braz. J. Microbiol. 40:238-240.

Otranto D., Testini G., Dantas-Torres F., Latrofa M.S., Diniz P.P., de Caprariis D., Lia R.P., Mencke N., Stanneck D., Capelli G. \& Breitschwerdt E.B. 2010. Diagnosis of canine vector-borne diseases in young dogs: a longitudinal study. J. Clin. Microbiol. 48:3316-3324.

Passos L.M., Geiger S.M., Ribeiro M.F., Pfister K. \& Zahler-Rinder M. 2005. First molecular detection of Babesia vogeli in dogs from Brazil. Vet. Parasitol. 127:81-85.

Perez M., Bodor M., Zhang C., Xiong Q. \& Rikihisa Y. 2006 Human infection with Ehrlichia canis accompanied by clinical signs in Venezuela. Ann. N.Y. Acad. Sci.1078:110-117.

Ramos C.A., Ramos R.A., Araújo F.R., Guedes D.S. Jr., Souza I.I., Ono T.M., Vieira A.S., Pimentel D.S., Ro E.O., Faustino M.A. \& Alves L.C. 2009. Comparison of nested-PCR with blood smear examination in detection of Ehrlichia canis and Anaplasma platys in dogs. Reva Bras. Parasitol. Vet. 1:58-62.

Rikihisa Y. 2000. Diagnosis of emerging ehrlichial diseases of dogs, horses, and humans. J. Vet. Intern. Med. 14:250-251.

Rey-Valeirón C., Criado-Fornelio A., Zavala E. \& Granados R. 2007. Parasitological and molecular characterization of a Venezuelan isolate of $B a$ besia canis. Revta Científica 1:21-27.

Rotondano T.E., Almeida H.K., Krawczak F.S., Santana V.L., Vidal I.F., Labruna M.B., Azevedo S.S., Almeida A.M. \& Melo M.A. 2015. Survey of Ehrlichia canis, Babesia spp. and Hepatozoon spp. in dogs from a semiarid region of Brazil. Revta Bras. Parasitol. 24:52-58.

Rufino C.P., Moraes P.H., Reis T., Campos R., Aguiar D.C., McCulloch J.A., Meneses A.M. \& Gonçalves E.C. 2013. Detection of Ehrlichia canis and Anaplasma platys DNA using multiplex PCR. Vector Borne Zoonotic Dis. 13:846-850.

Saito T.B., Cunha-Filho N.A., Pacheco R.C., Ferreira F., Pappen F.G., Farias N.A., Larsson C.E. \& Labruna M.B. 2008. Canine infection by rickettsiae and ehrlichiae in southern Brazil. Am. J. Trop. Med. Hyg. 79:102-108.

Salem N.Y. \& Farag H.S. 2014. Clinical, hematologic, and molecular findings in naturally occurring Babesia canis vogeli in egyptian dogs. Vet. Med. Int. 2014:270345

Sanogo Y.O., Davoust B., Inokuma H., Camicas J.L., Parola P. \& Brouqui P. 2003. First evidence of Anaplasma platys in Rhipicephalus sanguineus (Acari: Ixodida) collected from dogs in Africa. Onderstepoort J. Vet. Res. 70:205-212.

Sasaki M., Omobowale O., Tozuka M., Ohta K., Matsuu A., Nottidge H.O., Hi- 
rata H., Ikadai H. \& Oyamada T. 2007. Molecular survey of Babesia canis in dogs in Nigeria. J. Vet. Med. Sci. 69:1191-1193.

Shipov A., Klement E., Reuveni-Tager L., Waner T. \& Harrus S. 2008. Prognostic indicators for canine monocytic ehrlichiosis. Vet. Parasitol. 53:131-138.

Shortt H.E. 1973. Babesia canis: the life cycle and laboratory maintenance in its arthropod and mammalian hosts. Int. J. Parasitol. 3:119-148.

Silva G.C., Benitez A.N., Girotto A., Taroda A., Vidotto M.C., Garcia J.L., Freitas J.C., Arlington S.H. \& Vidotto 0. 2012a. Occurrence of Ehrlichia canis and Anaplasma platys in household dogs from northern Parana. Revta Bras. Parasitol. Vet. 21:379-385.

Silva A.B., Costa A.P., Sá J.C., Costa F.B., Santos A.C.G. \& Guerra R.M.S.N.C. 2012b. Detecção molecular de Babesia canis vogeli em cães e em Rhipicephalus sanguineus na mesorregião do oeste maranhense, nordeste brasileiro. Ciênc. Anim. Bras. 13:388-395.

Simpson R.M., Gaunt S.D., Hair J.A., Kocan K.M., Henk W.G. \& Casey H.W. 1991. Evaluation of Rhipicephalus sanguineus as a potential biologic vector of Ehrlichia platys. Am. J. Vet. Res. 52:1537-1541.

Sousa K.C., André M.R., Herrera H.M., Andrade G.B., Jusi M.M., Dos Santos L.L., Barreto W.T., Machado R.Z. \& Oliveira G.P. 2013. Molecular and serological detection of tick-borne pathogens in dogs from an area endemic for Leishmania infantum in Mato Grosso do Sul, Brazil. Revta Bras. Parasitol. Vet. 22:525-531.
Thrusfield M. 2007. Veterinary Epidemiology. 3rd ed. Blackwell Science, Oxford. 610p.

Ueno T.E., Aguiar D.M., Pacheco R.C., Richtzenhain L.J., Ribeiro M.G., Paes A.C., Megid J. \& Labruna M.B. 2009. Ehrlichia canis in dogs attended in a veterinary hospital from Botucatu, São Paulo State, Brazil. Revta Bras. Parasitol. Vet. 18:57-61.

Vieira R.F., Vieira T.S., Nascimento D.A., Martins T.F., Krawczak F.S., Labruna M.B., Chandrashekar R., Marcondes M., Biondo A.W. \& Vidotto O. 2013a. Serological survey of Ehrlichia species in dogs, horses and humans: zoonotic scenery in a rural settlement from southern Brazil. Revta Inst. Med. Trop. São Paulo 55:335-340.

Vieira T.S., Vieira R.F., Nascimento D.A., Tamekuni K., Toledo R.S., Chandrashekar R., Marcondes M., Biondo A.W. \& Vidotto O. 2013b. Serosurvey of tick-borne pathogens in dogs from urban and rural areas from Parana State, Brazil. Revta Bras. Parasitol. Vet. 22:104-109.

Xu D., Zhang J., Shi Z., Song C., Zheng X., Zhang Y., Hao Y., Dong H., Wei L., El-Mahallawy H.S.O., Kelly P., Xiong W., Wang H., Li J., Zhang X., Gu J. \& Wang C. 2015. Molecular detection of vector-borne agents in dogs from ten provinces of China. Parasit. Vectors 8:501.

Ybañez A.P., Perez Z.O., Gabotero S.R., Yandug R.T., Kotaro M. \& Inokuma H. 2012. First molecular detection of Ehrlichia canis and Anaplasma platys in ticks from dogs in Cebu, Philippin. Ticks Tick Borne Dis. 3:288-289. 